\title{
Optimization of Bioethanol Production Using Whole Plant of Water Hyacinth as Substrate in Simultaneous Saccharification and Fermentation Process
}

\author{
Qiuzhuo Zhang *, Chen Weng, Huiqin Huang, Varenyam Achal and Duanchao Wang \\ Shanghai Key Lab for Urban Ecological Processes and Eco-Restoration, School of Ecological and Environmental Sciences, \\ East China Normal University, Shanghai, China
}

\section{OPEN ACCESS}

Edited by:

Pankaj K. Arora,

Yeungnam University, South Korea

Reviewed by:

Uwe Strotmann,

Westfälische Hochschule, Germany Sachin Kumar,

Sardar Swaran Singh National Institute of Renewable Energy, India

*Correspondence: Qiuzhuo Zhang

qzhzhang@des.ecnu.edu.cn

Specialty section:

This article was submitted to Microbiotechnology, Ecotoxicology and Bioremediation,

a section of the journal

Frontiers in Microbiology

Received: 26 August 2015 Accepted: 27 November 2015 Published: 07 January 2016

Citation:

Zhang Q, Weng C, Huang H, Achal V and Wang $D$ (2016) Optimization of Bioethanol Production Using Whole Plant of Water Hyacinth as Substrate in Simultaneous Saccharification and Fermentation Process.

Front. Microbiol. 6:1411. doi: 10.3389/fmicb.2015.01411
Water hyacinth was used as substrate for bioethanol production in the present study. Combination of acid pretreatment and enzymatic hydrolysis was the most effective process for sugar production that resulted in the production of 402.93 mg reducing sugar at optimal condition. A regression model was built to optimize the fermentation factors according to response surface method in saccharification and fermentation (SSF) process. The optimized condition for ethanol production by SSF process was fermented at $38.87^{\circ} \mathrm{C}$ in $81.87 \mathrm{~h}$ when inoculated with $6.11 \mathrm{ml}$ yeast, where $1.291 \mathrm{~g} / \mathrm{L}$ bioethanol was produced. Meanwhile, $1.289 \mathrm{~g} / \mathrm{L}$ ethanol was produced during experimentation, which showed reliability of presented regression model in this research. The optimization method discussed in the present study leading to relatively high bioethanol production could provide a promising way for Alien Invasive Species with high cellulose content.

Keywords: water hyacinth, bioethanol, RSM, SSF, optimization methods

\section{INTRODUCTION}

The major source of energy comes from non-renewable fossil fuel that caused global warming, environmental degradation, and human health problems (Patil et al., 2014). The growing energy demands encourage scientists to explore low cost, environmental friendly and sustainable alternative energy sources (Cheng et al., 2015a,b; Lin et al., 2015; Merino-Pérez et al., 2015).

Bioethanol, as a clean, safe and renewable resource, is considered as a potential alternative to fossil fuels (Rezania et al., 2015). However, it is mainly produced from either starch- or sugar-rich crops that may raise land competition between food production and biomass energy utilization, and can lead to deforestation (Zhao and Xia, 2010; Das et al., 2015). Hence, lignocellulose is gradually considered as more attractive because of its low cost and easy availability (Valentine et al., 2012; Bayrakci and Koçar, 2014).

Water hyacinth (Eichornia crassipes), which is originated from Amazon basin (Barrett, 1989), is listed as one of the world's most invasive and recalcitrant weeds because of its availability in large quantities, extraordinary adaptive ability, and remarkable growth rate (Hu et al., 2015). It grows at an extreme rapid rate and produce almost 2 tons of biomass per acre and its population doubles every 5-15 days (Craft et al., 2003). Water hyacinth is usually blamed for depleting nutrients and oxygen from water bodies, increasing evapotranspiration, and reducing biodiversity, which could 
influence fishing, shipping, irrigation, and destroy aquatic ecosystem (Malik, 2007; Guerrero-Coronilla et al., 2015). This species was brought to mainland China in the 1930s. With its extremely high growth rate, this floating plant has infested many aquatic systems in 19 provinces of China (Xia et al., 2013). Moreover, water hyacinth is considered as an attractive raw material for the bioenergy production including bioethanol, hydrogen, and biochar in many tropical regions of the world among various types of lignocellulosic substances (Masto et al., 2013; Buller et al., 2015; Jiu et al., 2015; Zhang et al., 2015).

Due to its abundant availability and high carbohydrate contents, water hyacinth highly satisfies the requirements as a potential substrate for bioethanol production (Ganguly et al., 2012; Rezania et al., 2015). The dry biomass of water hyacinth mainly comprises low lignin (7-26\%) and high amount of cellulose (18-31\%) and hemicellulose (18-43\%), which can be easily hydrolyzed to reducing sugars and then fermented to bioethanol by effective yeasts (Bergier et al., 2012). However, there are many problems hindering the effective enzymatic hydrolysis. One of these problems is the lignin seal that prevents penetration by degrading enzymes (Taniguichi et al., 2005). Thus, many researchers tried to seek effective pretreatment methods to break the lignin seal (Forrest et al., 2010; Ma et al., 2010; Gao et al., 2013; Yan et al., 2015). Another bottleneck is the feedback inhibition of cellobiose on fermentation process after hydrolysis during bioethanol production (Guan et al., 2013; Ha et al., 2013; Cheng et al., 2015a,b). The most effective method to solve the feedback inhibition problem is simultaneous saccharification and fermentation (SSF), a process in which enzymatic process hydrolyzes lignocelluloses to sugars and ferments to bioethanol simultaneously, being already used in many lignocelluloses fermentation systems (Huang et al., 2013; Soares and Gouveia, 2013). However, there is no detail report on SSF process using water hyacinth as substrate.

In the present study, water hyacinth was collected from wastewater and pretreated. The major factors affecting the efficiency of SSF process were analyzed by response surface method (RSM) that provided an optimal fermentation parameter for bioethanol production by water hyacinth.

\section{MATERIALS AND METHODS}

\section{Materials and Microorganism}

Water hyacinth was obtained from Huangpu River, Minhang District, Shanghai, China. It was washed three times with tap water to remove extraneous matter and roots, and then smashed by grinder below 40 meshes for further use.

Cellulase extracted from Trichoderma viride was bought from Sinopharm Chemical Reagent Co., Ltd, Shanghai. The activity of cellulase is $15000 \mathrm{U} / \mathrm{g}$.

Saccharomyces cerevisiae was preserved in Shanghai Key Lab for Urban Ecological Processes and Eco-Restoration at East China Normal University (SHUES, ECNU), Shanghai. To prepare the yeast inoculum, one loop of $S$. cerevisiae spores was suspended in fluid enrichment medium $(10 \mathrm{~g} / \mathrm{L}$ yeast extract, $20 \mathrm{~g} / \mathrm{L}$ peptone and $20 \mathrm{~g} / \mathrm{L}$ glucose) for $24 \mathrm{~h}$. The exponential inoculum was centrifuged at $4000 \mathrm{r} / \mathrm{min}$ for $5 \mathrm{~min}$, followed by washing the precipitate by deionized water. After calculating dry weight of the yeast, $2 \mathrm{~g} / \mathrm{L}$ yeast inoculum was prepared finally.

\section{Pretreatment of Water Hyacinth}

Smashed water hyacinth was pretreated before enzymatic hydrolysis. Acid pretreatment $\left(1 \% \mathrm{H}_{2} \mathrm{SO}_{4}\right.$ at $100^{\circ} \mathrm{C}$ for $30 \mathrm{~min}$ when solid-liquid ratio was $1: 30)$, alkaline pretreatment $(0.5 \%$ $\mathrm{NaOH}$ at $40^{\circ} \mathrm{C}$ for 30 min when solid-liquid ratio was 1:16) and microwave-alkaline combined pretreatment (150 W microwave combined with $0.5 \% \mathrm{NaOH}$ for $0.5 \mathrm{~min}$ when solid-liquid ratio was 1:16) were used after optimization by orthogonal experiment. The specific conditions of the orthogonal experiment followed our previous research (Wang, 2015). Reducing sugars in hydrolysates were also determined.

\section{Enzymatic Hydrolysis}

The solid residue after pretreatment was collected by filtration and washed extensively with distilled water until neutral $\mathrm{pH}$. Subsequently, this pretreated water hyacinth was dried in the oven at $70^{\circ} \mathrm{C}$ to maintain a constant weight to be used as the substrate for enzymatic hydrolysis.

Cellulase dosage, hydrolysis temperature and time were selected as three factors for single factor experiment. The reducing sugars in hydrolysates were detected to determine an optimum enzymatic hydrolysis process.

\section{Saccharification and Fermentation Process}

One gram smashed water hyacinth sample was firstly pretreated by acid $\left(1 \% \mathrm{H}_{2} \mathrm{SO}_{4}\right)$ at the optimal condition followed by alkali $(6 \mathrm{~mol} / \mathrm{L} \mathrm{NaOH})$ was used to regulate $\mathrm{pH}$ value to 5.3. After that the mixture was autoclaved at $121^{\circ} \mathrm{C}$ for $20 \mathrm{~min}$, and $0.05 \mathrm{~g}$ cellulase with $0.05 \mathrm{~g} \mathrm{CaCl}_{2}$ were added to the pretreated sample to hydrolyze. Meanwhile, yeast inoculum was added into pretreated sample according to the experimental design along with $2.0 \mathrm{~g} / \mathrm{L}$ yeast extract, $0.2 \mathrm{~g} / \mathrm{L}\left(\mathrm{NH}_{4}\right)_{2} \mathrm{HPO}_{4}$ and $0.02 \mathrm{~g} / \mathrm{L}$ $\mathrm{MgSO}_{4}$. Nitrogen was aerated to exclude air in the system, and SSF was carried out at constant temperature shaker with the speed of $120 \mathrm{rpm}$. After SSF process, the fermented samples were centrifuged at $5000 \mathrm{rpm}$ for $8 \mathrm{~min}$ and supernatant was used for bioethanol determination.

\section{Response Surface Method}

The main factors that affect ethanol production, including fermentation temperature $\left(\mathrm{X}_{1}\right)$, fermentation time $\left(\mathrm{X}_{2}\right)$ and inoculums dosage $\left(\mathrm{X}_{3}\right)$, were chosen to be optimized by RSM. Seventeen group experiments designed by Box-Behnken were conducted to seek the highest ethanol production, which were listed in Table 2.

\section{Analytical Methods}

The moisture content of water hyacinth was detected by oven drying method at $105^{\circ} \mathrm{C}$ for three times, and the average value was calculated ultimately. Cellulose, hemicelluloses and lignin contents in water hyacinth were determined by the methods of Goering and Van soest (1970). The DNS method was used for the measurement of total reducing sugar contents (Miller, 1959). 
TABLE 1 | Constitution of water hyacinth in different organs.

\begin{tabular}{lcccc}
\hline & \multicolumn{4}{c}{ Contents (\%) } \\
\cline { 2 - 5 } Organs & Cellulose & Hemicellulose & Lignin & Others \\
\hline Leaf & $15.42 \pm 0.08$ & $29.75 \pm 0.15$ & $9.79 \pm 0.06$ & $45.04 \pm 0.29$ \\
Stem & $17.14 \pm 0.12$ & $21.82 \pm 0.06$ & $8.01 \pm 0.07$ & $53.03 \pm 0.25$ \\
Whole plant & $18.07 \pm 0.20$ & $28.21 \pm 0.11$ & $7.03 \pm 0.09$ & $46.69 \pm 0.40$ \\
\hline
\end{tabular}

TABLE 2 | Box-Behnken design and experimental results.

\begin{tabular}{lrrrr}
\hline & \multicolumn{3}{c}{ Factor } & \\
\cline { 2 - 4 } No. & $\mathbf{X}_{\mathbf{1}}$ & $\mathbf{X}_{\mathbf{2}}$ & $\mathbf{X}_{\mathbf{3}}$ & Bioethanol concentration (g/L) \\
\hline 1 & -1 & -1 & 0 & 1.07 \\
2 & 1 & -1 & 0 & 0.66 \\
3 & -1 & 1 & 0 & 0.56 \\
4 & 1 & 1 & 0 & 1.11 \\
5 & -1 & 0 & -1 & 0.49 \\
6 & 1 & 0 & -1 & 0.93 \\
7 & -1 & 0 & 1 & 0.43 \\
8 & 1 & 0 & 1 & 1.02 \\
9 & 0 & -1 & -1 & 0.63 \\
10 & 0 & 1 & -1 & 0.65 \\
11 & 0 & -1 & 1 & 0.65 \\
12 & 0 & 1 & 1 & 0.68 \\
13 & 0 & 0 & 0 & 1.14 \\
14 & 0 & 0 & 0 & 1.28 \\
15 & 0 & 0 & 0 & 1.21 \\
16 & 0 & 0 & 0 & 1.31 \\
17 & 0 & 0 & 0 & 1.23 \\
\hline
\end{tabular}

The bioethanol production during fermentation was measured using headspace sampling Gas Chromatography (GC, Agilent 7890A) method. HS-9A was selected as heated static headspace. The treated samples were examined by GC on a HP-5MS capillary column $(30 \mathrm{~m} \times 0.25 \mathrm{~mm} \times 0.25 \mu \mathrm{m})$ with FID detector. Nitrogen was used as carrier gas. All the experiments and sample injection were performed in triplicates, and the average values were represented and used ultimately. The conditions were as follow:

(1) Static headspace: Vial $70^{\circ} \mathrm{C}$; TR Line $90^{\circ} \mathrm{C}$; Loop $80^{\circ} \mathrm{C}$, $1 \mathrm{~mL}$; Loop Fill Time $1 \mathrm{~min}$; Ressuriz Time $0.2 \mathrm{~min}$; Vial EQ Time $10 \mathrm{~min}$.

(2) GC: The inlet temperature for GC was kept at $180^{\circ} \mathrm{C}$ with a Split ratio of $30: 1$. The oven temperature was kept at $180^{\circ} \mathrm{C}$ for $5 \mathrm{~min}$ at a flow rate of $2 \mathrm{~mL}-\mathrm{min}^{-1}$.

(3) FID: Temperature $80^{\circ} \mathrm{C}$; Hydrogen flow $30 \mathrm{~mL}-\mathrm{min}^{-1}$; Air flow $400 \mathrm{~mL}-\mathrm{min}^{-1}$; Make-up gas flow $25 \mathrm{~mL}-\mathrm{min}^{-1}$.

\section{RESULTS}

\section{Constitution of Water Hyacinth}

The average value of moisture content in water hyacinth sample was $90.85 \%$, which is much higher than the other cellulosic wastes. The contents of cellulose, hemicellulose and lignin in different organs of water hyacinth were determined (Table 1). Compared to leaf and stem, the whole plant of water hyacinth possessed a little higher cellulose (18.07\%) and hemicelluloses content $(28.21 \%)$, and low lignin content (7.03\%). Part of the erosion roots that was included in the whole plant of water hyacinth was removed before hydrolysis, so the composition of roots was not provided in Table $\mathbf{1}$. Considering the convenience and validity of utilization, the whole plant was finally selected as substrate for bioethanol production.

\section{Pretreatment and Hydrolysis of Water Hyacinth}

Three kinds of pretreatment methods, including acid pretreatment, alkali pretreatment and microwave-alkaline combined pretreatment, were used before hydrolysis and fermentation. Acid pretreatment was the most effective method to increase the sugar contents in samples. After grinding to 60 mesh, the water hyacinth sample was pretreated by $1 \%$ sulfuric acid at $100^{\circ} \mathrm{C}$ for $30 \mathrm{~min}$ when solid-liquid ratio was 1:30. An amount of $197.60 \mathrm{mg} / \mathrm{g}$ reducing sugars was obtained in hydrolysates. However, only $22.41 \mathrm{mg} / \mathrm{g}$ and $99.12 \mathrm{mg} / \mathrm{g}$ reducing sugars were obtained after alkaline pretreatment and microwavealkaline combined pretreatment, respectively. Calculated by Hu's method (Hu and Wen, 2008), 37.9, 4.30, and 19.01\% water hyacinth samples were converted into reducing sugars after acid pretreatment, alkaline pretreatment and microwave-alkaline combined pretreatment, respectively.

The surplus residue part of water hyacinth was hydrolyzed by cellulase after pretreatment. Various factors that influence cellulase hydrolysis, including cellulase dosage, enzyme temperature and reaction time, were optimized by single factor experiment (Figures 1A-C). The result showed that the yield of reducing sugar could reach $205.33 \mathrm{mg}$ at $45^{\circ} \mathrm{C}$ at the end of $96 \mathrm{~h}$ when $0.05 \mathrm{~g}$ cellulase was added. Thus, totally $402.93 \mathrm{mg}$ ( $197.60 \mathrm{mg}$ in hydrolysates and $205.33 \mathrm{mg}$ by residue hydrolysis) reducing sugar could be produced at the optimal condition.

\section{Regression Model and Significance Test by Response Surface Method in Simultaneous Saccharification and Fermentation Process}

The Box-Behnken design and experimental results were listed in Table 2. Variance test and regression were analyzed by Designexpert software after manual operation, which was shown in Table 3. It was showed that the regression model was highly significant $(P<0.05)$ and the regression equation obtained in the present study could predict the response value effectively.

The monomial expression $\mathrm{X}_{1}(P=0.0064)$ was significant, whereas $\mathrm{X}_{2}(P=0.9766)$ and $\mathrm{X}_{3}(P=0.8146)$ were nonsignificant. Thus, fermentation temperature was the most crucial factor that could influence SSF process. The binomial expression $\mathrm{X}_{3}{ }^{2}(P=0.0001)$ was extremely significant, $\mathrm{X}_{2}{ }^{2}$ $(P=0.0034)$ was relatively significant, and there was certain significance for $\mathrm{X}_{1}^{2}(P=0.0209)$. The results indicated the primacy sequence influencing SSF process as fermentation temperature $>$ inoculums dosage $>$ fermentation time. 

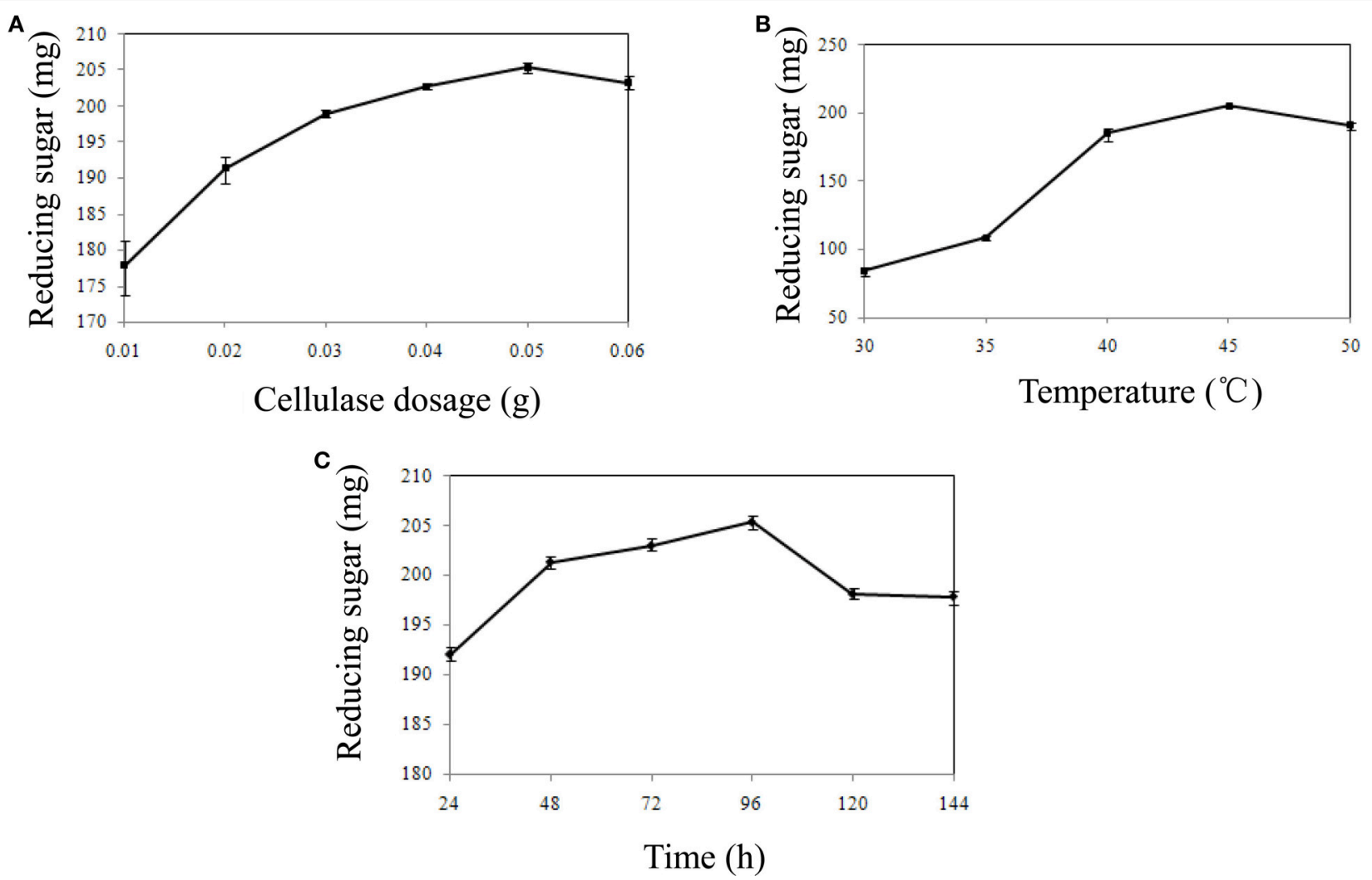

FIGURE 1 | The influence of hydrolysis factors on reducing sugar production. (A) The influence of cellulase dosage on reducing sugar production. (B) The influence of temperature on reducing sugar production. (C) The influence of time on reducing sugar production.

TABLE 3 | Variance analysis of regression equation.

\begin{tabular}{lrrrrr}
\hline Source & Sum of squares & df & Mean square & $\boldsymbol{F}$-value & $P$-value \\
\hline Model & 1.34 & 7 & 0.19 & 13.99 & 0.0004 \\
$X_{1}$ & 0.17 & 1 & 0.17 & 12.47 & 0.0064 \\
$X_{2}$ & $1.250 E-005$ & 1 & $1.250 E-005$ & $9.106 \mathrm{E}-004$ & 0.9766 \\
$X_{3}$ & $8.000 E-004$ & 1 & $8.000 E-004$ & 0.058 & 0.8146 \\
$X_{1} X_{2}$ & 0.23 & 1 & 0.23 & 16.78 & 0.0027 \\
$X_{1}{ }^{2}$ & 0.11 & 1 & 0.11 & 7.80 & 0.0209 \\
$X_{2}{ }^{2}$ & 0.21 & 1 & 0.21 & 15.46 & 0.0034 \\
$X_{3}{ }^{2}$ & 0.54 & 1 & 0.54 & 39.09 & 0.0001 \\
Residual & 0.12 & 9 & 0.014 & - & - \\
Lack of fit & 0.11 & 5 & 0.021 & 4.91 & 0.0743 \\
Pure error & 0.017 & 4 & $4.330 \mathrm{E}-003$ & - & - \\
Cor total & 1.47 & 16 & - & - & -
\end{tabular}

The secondary multivariate regression equation obtained from Design-expert software was $Y=1.23+0.15 \mathrm{X}_{1}-(1.250 \mathrm{E}-$ $\left.003 \mathrm{X}_{2}\right)+0.010 \mathrm{X}_{3}+0.24 \mathrm{X}_{1} \mathrm{X}_{2}-0.16 \mathrm{X}_{1}^{2}-0.22 \mathrm{X}_{2}^{2}-$ $0.36 \mathrm{X}_{3}^{2}$. According to the secondary multivariate regression equation and regression model, the optimal condition for bioethanol production by SSF process was fermented at $38.87^{\circ} \mathrm{C}$ for $81.87 \mathrm{~h}$ when inoculated with $6.11 \mathrm{ml}$ yeast. The ethanol yield could achieve $1.291 \mathrm{~g} / \mathrm{L}$ at this condition by our regression model. Furthermore, $1.289 \mathrm{~g} / \mathrm{L}$ ethanol was produced during real experimentation at this condition, which is very close to our regression model.

The optimal factors and factor levels could be determined and the interaction effects between two factors could be revealed by response surface and contour map. The response surface and contour map of the secondary multivariate regression equation was shown in Figures $\mathbf{2 A}, \mathbf{B}, \mathbf{3 A}, \mathbf{B}$, and 4A,B, respectively. The results showed a remarkable significant interaction between fermentation temperature $\left(\mathrm{X}_{1}\right)$ and fermentation time $\left(\mathrm{X}_{2}\right)$. However, there was no significant interaction between fermentation time $\left(\mathrm{X}_{2}\right)$ and inoculums dosage $\left(\mathrm{X}_{3}\right)$. Moreover, there was no significant interaction between fermentation temperature $\left(\mathrm{X}_{1}\right)$ and inoculums dosage $\left(\mathrm{X}_{3}\right)$, either. Fermentation temperature $\left(\mathrm{X}_{1}\right)$ was the most important factor influencing SSF process in the present study.

\section{DISCUSSION}

Based on our results, the whole plant of water hyacinth possesses the highest cellulose content compared to stem and leaf after removing its rotten part. Therefore, it was selected as substrate for ethanol production, which could make full use of the whole plant.

Biofuel production from cellulosic materials greatly depends on the disruption of its complex lignocellulosic structure, 


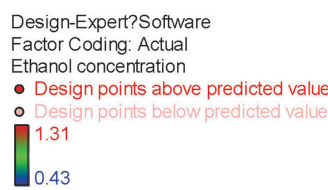

$\mathrm{X} 1=\mathrm{A}:$ Fermentation time $\mathrm{X} 2$ = B: Fermentation temperature

Actual Factor

C: Inoculum dosage $=0.00$

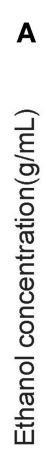

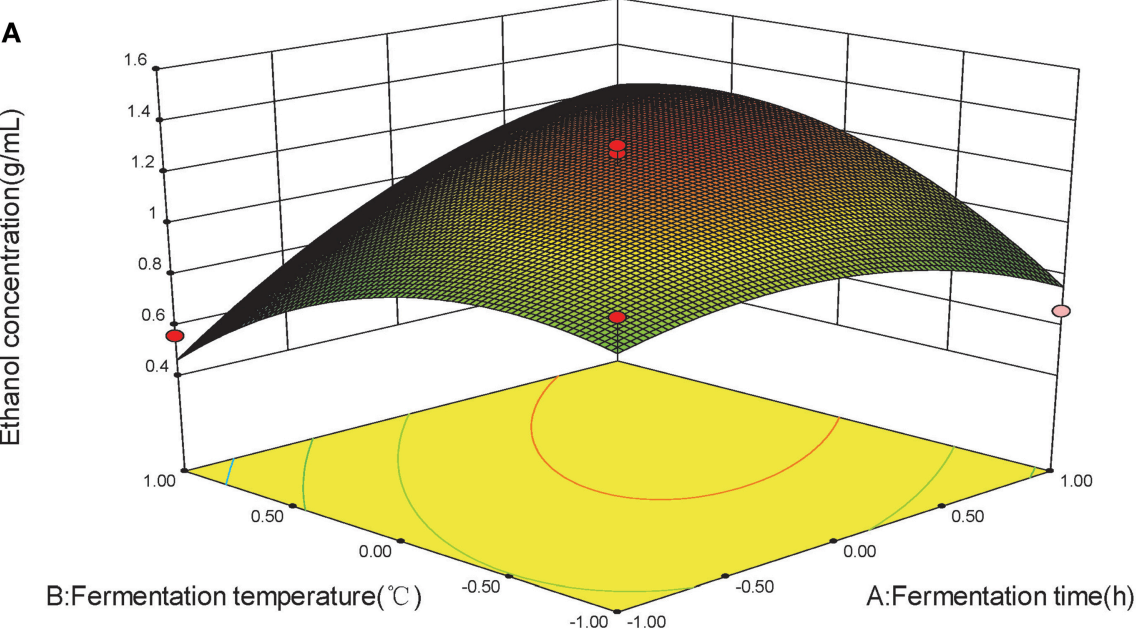

B

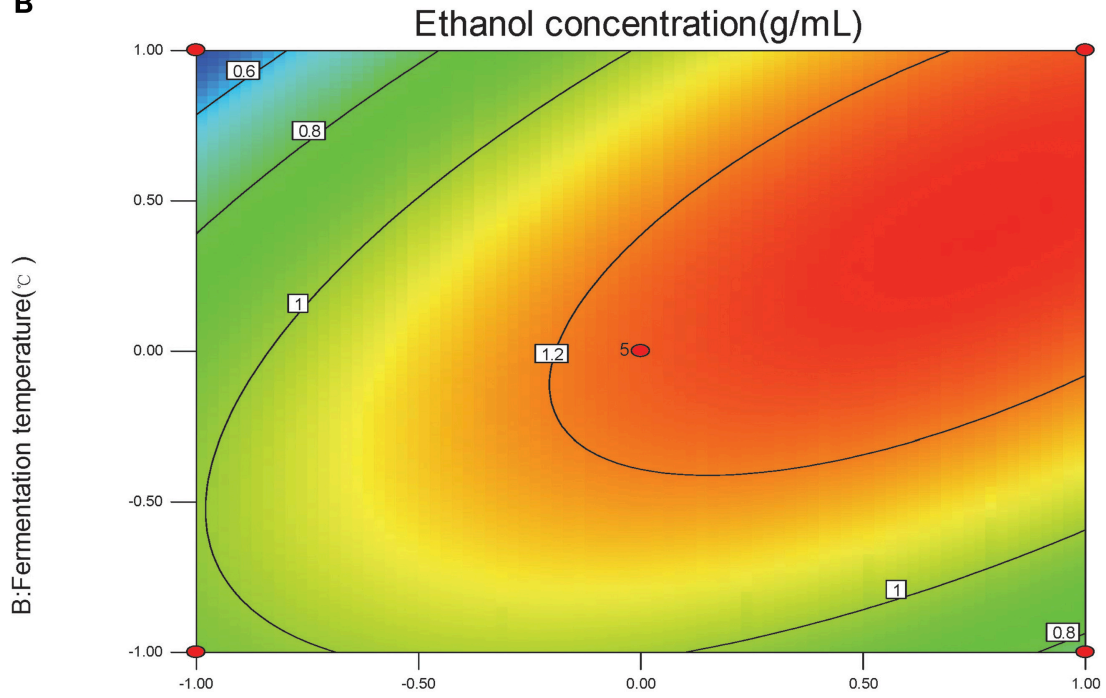

A:Fermentation time(h)
Design-Expert? Software
Factor Coding: Actual

Ethanol concentration

- Design Points

1.31

0.43

$\mathrm{X} 1=\mathrm{A}:$ Fermentation time X2 = B: Fermentation temperature

Actual Factor

C: Inoculum dosage $=0.00$

FIGURE 2 | (A,B) Response of bioethanol production to fermentation time and fermentation temperature.

which is recalcitrant to biodegradation. Hence, a suitable and effective pretreatment method should be selected for different cellulosic substrates. Various kinds of pretreatment methods, including acid, alkali, microwave, liquid hot water and compound pretreatments, were investigated nowadays for cellulose hydrolysis (Forrest et al., 2010; Ma et al., 2010; Gao et al., 2013; Timung et al., 2015; Yan et al., 2015). In our previous study, alkaline pretreatment was optimal for bioethanol production by rice straw hydrolysis (Zhang and Cai, 2008). However, acid pretreatment was the most effective method for bioethanol production by water hyacinth compared to other pretreatment methods in this study. The possible mechanism involves dissolution of hemicellulose causing loosening of the structure of raw material, which makes acid pretreatment an important method for the production ofreducing sugars ( $\mathrm{Ma}$ et al., 2010; Xia et al., 2013). After pretreated by acid, the loosen substrate could increase the contact area between cellulose and cellulase. Meanwhile, it might prevent unproductive binding of enzymes to lignin, thus facilitates reducing sugar production (Zhang et al., 2009).

Cellulase usage is a huge cost in bioethanol production process. Large amounts of cellulases are needed to hasten the 


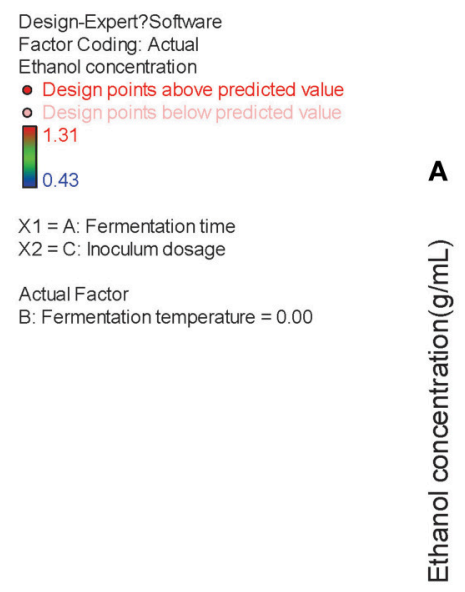

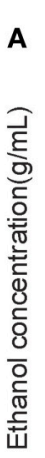
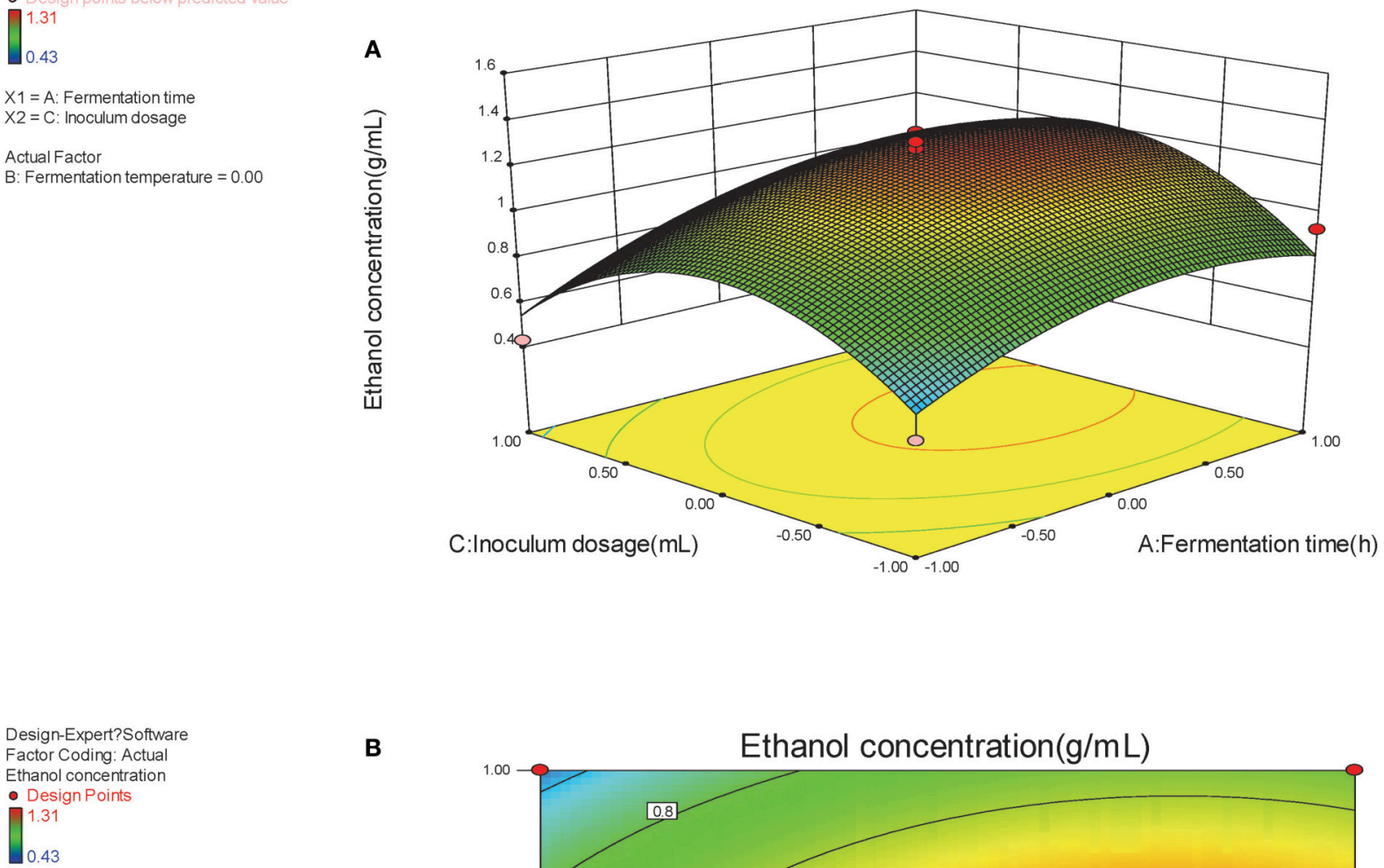

B

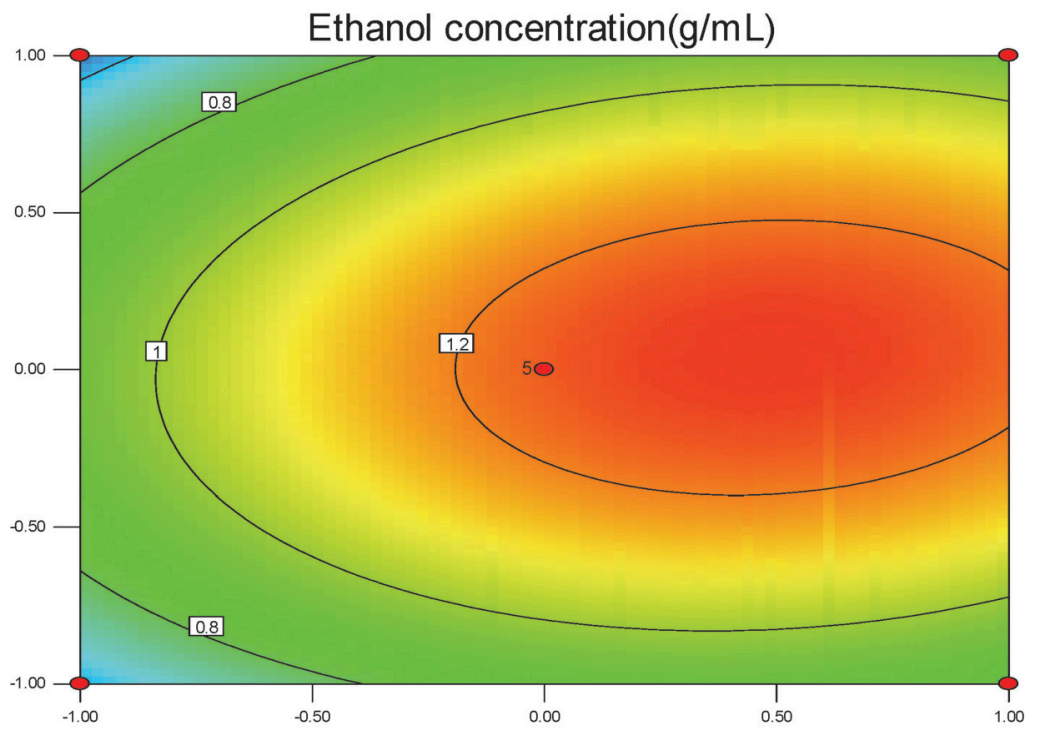

$\mathrm{X} 2=\mathrm{C}:$ Inoculum dosage

Actual Factor

B. Fermentation temperature $=0.00$

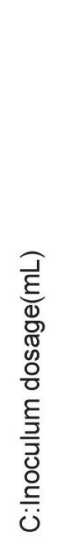

A:Fermentation time(h)

FIGURE 3 | (A,B) Response of bioethanol production to fermentation time and inoculums dosage.

hydrolysis process, thereby increasing the cost of the whole processing. In addition, enzyme recycling becomes difficult because of the adsorption of cellulases to residual cellulosic materials (Zhang et al., 2009). Thus, many factors, such as cellulase dosage, enzyme temperature and reaction time, are urgently necessary to be optimized to reduce the cost of bioethanol production. After optimization of such important parameters in the present study, $402.93 \mathrm{mg}(197.60 \mathrm{mg}$ in hydrolysates, and $205.33 \mathrm{mg}$ by residue hydrolysis) reducing sugar was produced. The theoretical yield of reducing sugar that produced by water hyacinth was $521.30 \mathrm{mg}$, counted by Hu's method ( $\mathrm{Hu}$ and Wen, 2008). Therefore, the real yield of achieved reducing sugar was $77.29 \%$ of the theoretical yield by our optimized technique, and is more effective method compared to other reports, which only produce reducing sugars from the hydrolysates (Ma et al., 2010; Yan et al., 2015). 


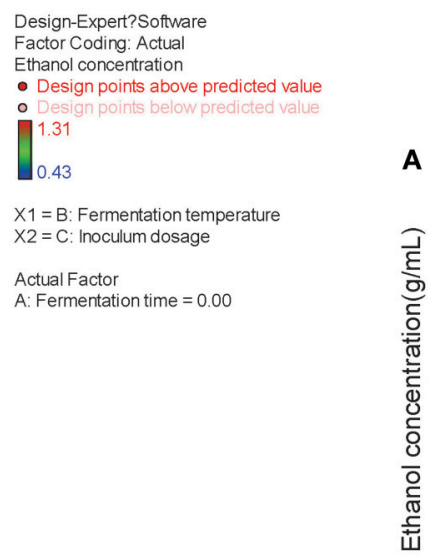

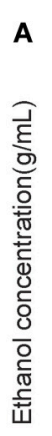

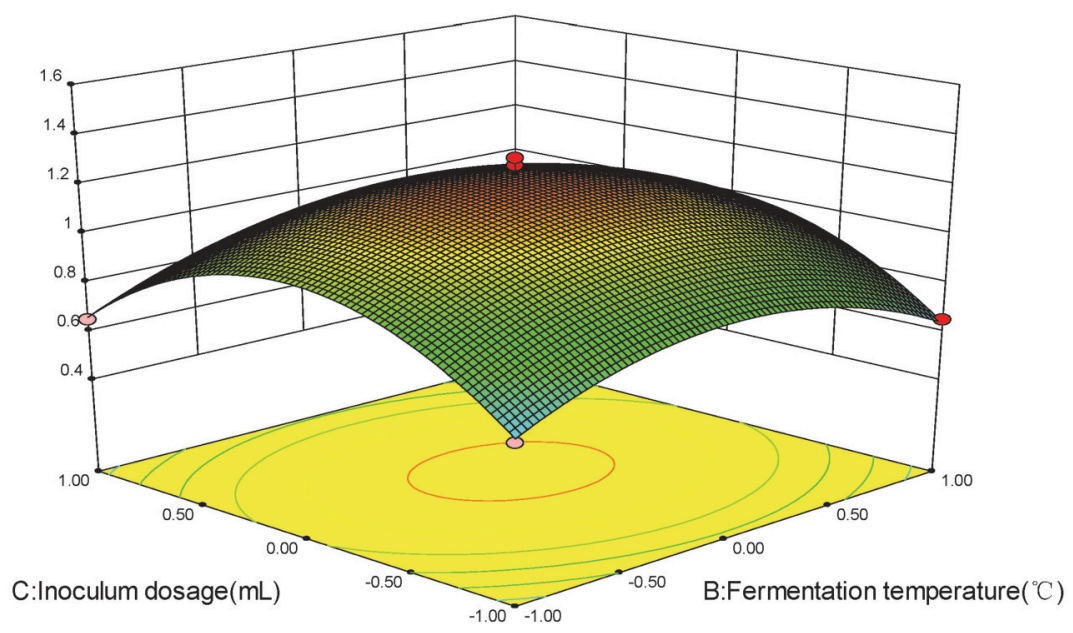

Design-Expert?Software

Factor Coding: Actual

Ethanol concentration

- Design

0.43

$\mathrm{X} 1$ = B: Fermentation temperature $\mathrm{X} 2$ = $\mathrm{C}$ : Inoculum dosage

Actual Factor

A: Fermentation time $=0.00$

B

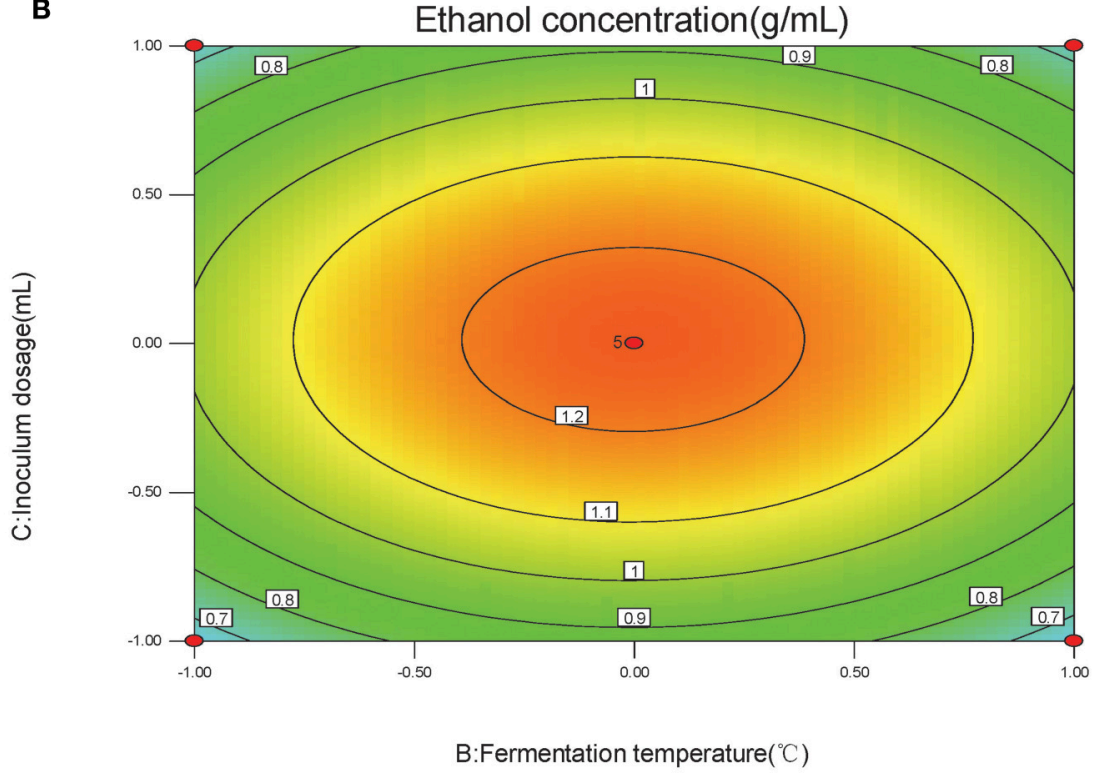

FIGURE 4 | (A,B) Response of bioethanol production to fermentation temperature and inoculums dosage.

However, pentose (such as xylose) sugar could not be digested using S. cerevisiae and remained unchanged during fermentation (Zhang and Cai, 2008). Hence, exploring a hexose-pentose cofermentation system by genetic engineering method could be a promising way to improve bioethanol production by cellulosic materials.

According to our regression model, the ethanol yield could achieve $1.291 \mathrm{~g} / \mathrm{L}$ at the optimum condition, while $1.289 \mathrm{~g} / \mathrm{L}$ ethanol was produced by our real experiment at this condition, which is very close to the predicted model. These results showed the reliability of presented regression model. In terms of factors, which influenced SSF process, fermentation temperature $\left(\mathrm{X}_{1}\right)$ was the most important compared to other factors, as temperature is crucial for growth and activity of cellulase and S. cerevisiae. Meanwhile, bioethanol production possessed a relatively high value that proved a fact that the SSF process is more effective than SSF separately (Wang et al., 2013; Asada et al., 2015; Saha et al., 2015). Although SSF could solve 
the feedback inhibition problem of cellobiose on fermentation process, it has some drawbacks, such as gap for the optimum temperature and $\mathrm{pH}$ conditions between cellulase and $S$. cerevisiae. Thus, a pivotal research field is required to develop and regulate a suitable condition for microorganisms in SSF process.

In addition, compared to other cellulosic materials, the moisture content in water hyacinth is much higher that could be solved during bioethanol production by fermentation of water hyacinth in future (Mishima et al., 2008). Further, there are some inhibitors (furfural, furan, phenols, etc.) in the hydrolysates that could destroy the fermentation process (Kalyani et al., 2012; Moreno et al., 2012; Wang et al., 2014), and an effective method to minimize the inhibitors production is urgently required in the future study. Moreover, the solid loading in enzymatic hydrolysis and SSF process might be another important factor, which need to be optimized in our future work.

\section{REFERENCES}

Asada, C., Sasaki, C., Takamatsu, T., and Nakamura, Y. (2015). Conversion of steam-exploded cedar into ethanol using simultaneous saccharification, fermentation and detoxification process. Bioresour. Technol. 176, 203-209. doi: 10.1016/j.biortech.2014.11.039

Barrett, S. C. H. (1989). Water weed invasions. Sci. Am. 264, 90-97. doi: 10.1038 /scientificamerican1089-90

Bayrakci, A. G., and Koçar, G. (2014). Second-generation bioethanol production from water hyacinth and duckweed in Izmir: a case study. Renew. Sustain. Energy Rev. 30, 306-316. doi: 10.1016/j.rser.2013.10.011

Bergier, I., Salis, S. M., Miranda, C. H. B., Ortega, E., and Luengo, C. A. (2012). Biofuel production from water hyacinth in the Pantanal wetland. Ecohydrol. Hydrobiol. 12, 77-84. doi: 10.2478/v10104-011-0041-4

Buller, L. S., Ortega, E., Bergier, I., Mesa-Pérez, J. M., Salis, S. M., and Luengo, C. A. (2015). Sustainability assessment of water hyacinth fast pyrolysis in the Upper Paraguay River basin, Brazil. Sci. Total Environ. 532, 281-291. doi: 10.1016/j.scitotenv.2015.05.129

Cheng, J., Lin, R., Song, W., Xia, A., Zhou, J., and Cen, K. (2015a). Enhancement of fermentative hydrogen production from hydrolyzed water hyacinth with activated carbon detoxification and bacteria domestication. Int. J. Hydrogen Energy 40, 2545-2551. doi: 10.1016/j.ijhydene.2014.12.097

Cheng, Y. S., Chen, K. Y., and Chou, T. H. (2015b). Concurrent calcium peroxide pretreatment and wet storage of water hyacinth for fermentable sugar production. Bioresour. Technol. 176, 267-272. doi: 10.1016/j.biortech.2014.11.016

Craft, C. P., Megonigal, S., Broome, J., Stevenson, R., Freese, J., Cornell, L., et al. (2003). The pace of ecosystem development of constructed Spartina alterniflora marshes. Ecol. Appl. 13, 1417-1432. doi: 10.1890/02-5086

Das, S., Bhattacharya, A., Haldar, S., Ganguly, A., Gu, S., Ting, Y. P., et al. (2015). Optimization of enzymatic saccharification of water hyacinth biomass for bio-ethanol: comparison between artificial neural network and response surface methodology. Sustain. Mater. Technol. 3, 17-28. doi: 10.1016/j.susmat.2015.01.001

Forrest, A. K., Hernandez, J., and Holtzapple, M. T. (2010). Effects of temperature and pretreatment conditions on mixed-acid fermentation of water hyacinths using a mixed culture of thermophilic microorganisms. Bioresour. Technol. 101, 7510-7515. doi: 10.1016/j.biortech.2010.04.049

Ganguly, A., Chatterjee, P. K., and Dey, A. (2012). Studies on ethanol production from water hyacinth-a review. Renew. Sustain. Energy Rev. 16, 966-972. doi: 10.1016/j.rser.2011.09.018

Gao, J., Chen, L., Yan, Z., and Wang, L. (2013). Effect of ionic liquid pretreatment on the composition, structure and biogas production of

\section{CONCLUSION}

As a conventional invasive weed, water hyacinth proved its feasibility for bioethanol energy production. In our experiment, $402.93 \mathrm{mg}$ reducing sugar and $1.289 \mathrm{~g} / \mathrm{L}$ bioethanol were achieved using water hyacinth substrate in Simultaneous SSF process after being optimized by RSM. This relatively high bioethanol production indicates that water hyacinth is a promising plant in research and development of sustainable energy.

\section{ACKNOWLEDGMENTS}

This research is supported by grants from National Natural Science Foundation of China (NSFC, No. 31400513), Ministry of Education of People's Republic of China (No.20120076120019) and Shanghai Science and Technology Committee (No.12ZR1409100).

water hyacinth (Eichhornia crassipes). Bioresour. Technol. 132, 361-364. doi: 10.1016/j.biortech.2012.10.136

Goering, H. K., and Van soest, P. J. (1970). Forage Fibre Analysis. Agriculture Handbook. Washington, DC: Agricultural Research Services, United States Department of Agriculture.

Guan, D., Li, Y., Shiroma, R., Ike, M., and Tokuyasu, K. (2013). Sequential incubation of Candida shehatae and ethanol-tolerant yeast cells for efficient ethanol production from a mixture of glucose, xylose and cellobiose. Bioresour. Technol. 132, 419-422. doi: 10.1016/j.biortech.2012.12.040

Guerrero-Coronilla, I., Morales-Barrera, L., and Cristiani-Urbina, E. (2015). Kinetic, isotherm and thermodynamic studies of amaranth dye biosorption from aqueous solution onto water hyacinth leaves. J. Environ. Manage. 152, 99-108. doi: 10.1016/j.jenvman.2015.01.026

Ha, S. J., Kim, S. R., Kim, H., Du, J., Cate, J. H. D., and Jin, Y. S. (2013). Continuous co-fermentation of cellobiose and xylose by engineered Saccharomyces cerevisiae. Bioresour. Technol. 149, 525-531. doi: 10.1016/j.biortech.2013. 09.082

Hu, Z., Ma, X., and Li, L. (2015). Optimal conditions for the catalytic and noncatalytic pyrolysis of water hyacinth. Energy Convers. Manage. 94, 337-344. doi: 10.1016/j.enconman.2015.01.087

$\mathrm{Hu}, \mathrm{Z}$., and Wen, Z. (2008). Enhancing enzymatic digestibility of switchgrass by microwave-assisted alkali pretreatment. Biochem. Eng. J. 38, 369-378. doi: 10.1016/j.bej.2007.08.001

Huang, Y. H., Jin, Y. L., Fang, Y., Li, Y. H., Zhang, G. H., Xiao, Y., et al. (2013). Simultaneous saccharification and fermentation (SSF) of non-starch polysaccharides and starch from fresh tuber of Canna edulis ker at a high solid content for ethanol production. Biomass Bioenergy 52, 8-14. doi: 10.1016/j.biombioe.2013.02.023

Jiu, B., Li, B. X., and Yu, Q. J. (2015). Effects of $\mathrm{Pb}$ on pyrolysis behavior of water hyacinth. J. Anal. Appl. Pyrolysis 112, 270-275. doi: 10.1016/j.jaap.2015. 01.015

Kalyani, D., Dhiman, S. S., Kim, H., Jeya, M., Kim, I. W., and Lee, J. K. (2012). Characterization of a novel laccase from the isolated Coltricia perennis and its application to detoxification of biomass. Process Biochem. 47, 671-678. doi: 10.1016/j.procbio.2012.01.013

Lin, R., Cheng, J., Song, W., Ding, L., Xie, B., Zhou, J., et al. (2015). Characterisation of water hyacinth with microwave-heated alkali pretreatment for enhanced enzymatic digestibility and hydrogen/methane fermentation. Bioresour. Technol. 182, 1-7. doi: 10.1016/j.biortech.2015.01.105

Ma, F., Yang, N., Xu, C., Yu, H., Wu, J., and Zhang, X. (2010). Combination of biological pretreatment with mild acid pretreatment for enzymatic hydrolysis and ethanol production from water hyacinth. Bioresour. Technol. 101, 9600-9604. doi: 10.1016/j.biortech.2010.07.084 
Malik, A. (2007). Environmental challenge vis a vis opportunity: the case of water hyacinth. Environ. Int. 33, 122-138. doi: 10.1016/j.envint.2006.08.004

Masto, R. E., Kumar, S., Rout, T. K., Sarkar, P., George, J., and Ram, L. C. (2013). Biochar from water hyacinth (Eichornia crassipes) and its impact on soil biological activity. Catena 111, 64-71. doi: 10.1016/j.catena.2013.06.025

Merino-Pérez, O., Martínez-Palou, R., Labidi, J., and Luque, R. (2015). Microwaveassisted pretreatment of lignocellulosic biomass to produce biofuels and valueadded products. Prod. Biofuels Chem. Microw. 3, 197-224. doi: 10.1007/978-94017-9612-5 10

Miller, G. L. (1959). Use of dinitrosalicylic acid reagent for determination of reducing sugars. Anal. Chem. 31, 426-428. doi: 10.1021/ac60147a030

Mishima, D., Kuniki, M., Sei, K., Soda, S., Ike, M., and Fujita, M. (2008). Ethanol production from candidate energy crops: water hyacinth (Eichhornia crassipes) and water lettuce (Pistia stratiotes L.). Bioresour. Technol. 99, 2495-2500. doi: 10.1016/j.biortech.2007.04.056

Moreno, A. D., Ibarra, D., Fernández, J., and Ballesteros,M. (2012). Different laccase detoxification strategies for ethanol production from lignocellulosic biomass by the thermotolerant yeast Kluyveromyces marxianus CECT 10875. Bioresour. Technol. 106, 101-109. doi: 10.1016/j.biortech.2011. 11.108

Patil, J. H., AntonyRaj, M., Shankar, B. B., Shetty, M. K., and Pradeep Kumar, B. P. (2014). Anaerobic co-digestion of water hyacinth and sheep waste. Energy Procedia 52, 572-578. doi: 10.1016/j.egypro.2014.07.112

Rezania, S., Ponraj, M., Md Din, M. F., Songip, A. R., Sairan, F. M., and Chelliapan, S. (2015). The diverse applications of water hyacinth with main focus on sustainable energy and production for new era: an overview. Renew. Sustain. Energy Rev. 41, 943-954. doi: 10.1016/j.rser.2014.09.006

Saha, B. C., Nichols, N. N., Qureshi, N., Kennedy, G. J., Iten, L. B., and Cotta, M. A. (2015). Pilot scale conversion of wheat straw to ethanol via simultaneous saccharification and fermentation. Bioresour. Technol. 175, 17-22. doi: 10.1016/j.biortech.2014.10.060

Soares, M. L., and Gouveia, E. R. (2013). Influence of the alkaline delignification on the simultaneous saccharification and fermentation (SSF) of sugar cane bagasse. Bioresour. Technol. 147, 645-648. doi: 10.1016/j.biortech.2013. 08.103

Taniguichi, M., Suzuki, H., Watanabe, D., Sakai, K., Hoshino, K., and Tanaka, T. (2005). Evaluation of pretreatment with Pleurotus ostreatus for enzymatic hydrolysis of rice straw. J. Biosci. Bioeng. 100, 637-643. doi: 10.1263/jbb. 100.637

Timung, R., Mohan, M., Chilukoti, B., Sasmal, S., Banerjee, T., and Goud, V. V. (2015). Optimization of dilute acid and hot water pretreatment of different lignocellulosic biomass: a comparative study. Biomass Bioenergy 81, 9-18. doi: 10.1016/j.biombioe.2015.05.006

Valentine, J., Clifton-Brown, J., Hastings, A., Robson, P., Allison, G., and Smith, P. (2012). Food vs. fuel: the use of land for lignocellulosic 'next generation' energy crops that minimize competition with primary food production. Global Change Biol. Bioenergy 4, 1-19. doi: 10.1111/j.1757-1707.2011.01111.x

Wang, D. (2015). Optimization of Ethanol Production by Saccharification and Fermentation From Water Hyacinth. M.S. thesis, East China Normal University, Shanghai.

Wang, L., Luo, Z., and Shahbazi, A. (2013). Optimization of simultaneous saccharification and fermentation for the production of ethanol from sweet sorghum (Sorghum bicolor) bagasse using response surface methodology. Ind. Crops Prod. 42, 280-291. doi: 10.1016/j.indcrop.2012.06.005

Wang, W., Liu, Y., Li, T., and Zhou, M. (2014). Heterogeneous Fenton catalytic degradation of phenol based on controlled release of magnetic nanoparticles. Chem. Eng. J. 242, 1-9. doi: 10.1016/j.cej.2013.12.080

Xia, A., Cheng, J., Song, W., Yu, C., Zhou, J., and Cen, K. (2013). Enhancing enzymatic saccharification of water hyacinth through microwave heating with dilute acid pretreatment for biomass energy utilization. Energy 61, 158-166. doi: 10.1016/j.energy.2013.09.019

Yan, J., Wei, Z., Wang, Q., He, M., Li, S., and Irbis, C. (2015). Bioethanol production from sodium hydroxide/hydrogen peroxide pretreated water hyacinth via simultaneous saccharification and fermentation with a newly isolated thermo tolerant Kluyveromyces marxianu strain. Bioresour. Technol. 193, 103-109. doi: 10.1016/j.biortech.2015.06.069

Zhang, F., Wang, X., Yin, D., Peng, B., Tan, C., Liu, Y., et al. (2015). Efficiency and mechanisms of $\mathrm{Cd}$ removal from aqueous solution by biochar derived from water hyacinth (Eichornia crassipes). J. Environ. Manage. 153, 68-73. doi: 10.1016/j.jenvman.2015.01.043

Zhang, Q., and Cai, W. (2008). Enzymatic hydrolysis of alkali-pretreated rice straw by Trichoderma reesei ZM4-F3. Biomass Bioenergy 32, 1130-1135. doi: 10.1016/j.biombioe.2008.02.006

Zhang, Q., He, G., Wang, J., Cai, W., and Xu, Y. (2009). Mechanisms of the stimulatory effects of rhamnolipid biosurfactant on rice straw hydrolysis. Appl. Energy 86, S233-S237. doi: 10.1016/j.apenergy.2009.04.030

Zhao, J., and Xia, L. (2010). Ethanol production from corn stover hemicellulosic hydrolysate using immobilized recombinant yeast cells. Biochem. Eng. J. 49, 28-32. doi: 10.1016/j.bej.2009.11.007

Conflict of Interest Statement: The authors declare that the research was conducted in the absence of any commercial or financial relationships that could be construed as a potential conflict of interest.

Copyright (c) 2016 Zhang, Weng, Huang, Achal and Wang. This is an open-access article distributed under the terms of the Creative Commons Attribution License (CC $B Y)$. The use, distribution or reproduction in other forums is permitted, provided the original author(s) or licensor are credited and that the original publication in this journal is cited, in accordance with accepted academic practice. No use, distribution or reproduction is permitted which does not comply with these terms. 